\title{
Histopathological analysis of testicular tumors
}

\author{
Karki S ${ }^{1}$, Bhatta RR ${ }^{1}$ \\ ${ }^{I}$ Department of Pathology, Institute of Medicine, Tribhuvan university teaching hospital, Kathmandu, Nepal
}

\section{Keywords:}

Germ cell tumors;

Testicular tumors;

Undescended

\begin{abstract}
Background: Testicular cancers are rare in most countries. However, in many western countries its incidence has been increasing since the middle of the twentieth century. A definite geographic and racial distribution is seen in testicular tumors. The purpose of the study was to analyze the pattern and distribution of testicular cancers in one of the hospital in Nepal.
\end{abstract}

Materials and methods: This was a retrospective study, in which cases were retrieved from the computer database between September 2006 and August 2011 in the department of Pathology. Pertinent data like age and histopathology of tumor were collected from the surgical pathology reports.

Results: Testicular tumors were uncommon, comprising only $11.4 \%$ (8/70 cases) of all testicular lesions. Most of these tumors (50\%) were seen between 4th and 5th decades. Germ cell tumors were the commonest tumors $(62.5 \%)$, among which seminomas and mixed germ cell tumors were most frequently encountered, two cases each. Thirty percent of the biopsies consisted of undescended testis and none of them showed malignancy. Other tumors diagnosed were Non Hodgkin Lymphoma, leukemic infiltration and metastasis.

Conclusion: Testicular tumors are uncommon in our population. As evident in other parts of the world, germ cell tumor was common in this study as well. However, unlike in Western population, no tumor was seen in undescended testis.

\section{INTRODUCTION}

Testicular cancers are rare in most parts of the world, with age standardized incidence rate ranging from $1 / 100,000$ in Asian and African/ African American populations to 9.2/100,000 in Denmark. ${ }^{1}$ Its incidence has been increasing since the middle of twentieth century in many Western countries, ${ }^{2-5}$ with the potential exception of children ages 14 years or less, where little variation is observed. ${ }^{6,7}$

Though the etiology of testicular cancers is not well understood, various factors like cryptorchidism, trauma,

\section{Correspondence:}

Dr. Shovana Karki, MD

Department of Pathology, Institute of Medicine, Tribhuvan university teaching hospital, Kathmandu, Nepal

Email:shovana_karki@hotmail.com infections, genetic and endocrine factors appear to play a role in their development. ${ }^{8}$

A definite geographic and racial distribution is seen in testicular tumors. The age distribution of testicular cancers is also distinct from other cancers. ${ }^{2}$ The purpose of this study was to analyze the pattern and distribution of testicular tumors in one of the university hospital in Kathmandu.

\section{MATERIALS AND METHODS}

This was a retrospective study, in which cases were retrieved from computer database between September 2006 and August 2011, in the department of pathology.

Pertinent data like age and histopathology were collected 
from the surgical pathology report and analyzed. Software SPSS 10 version was used to analyze data wherever applicable.

\section{RESULTS}

There were a total of $70(0.27 \%)$ testicular biopsies of 26,753 biopsies received in the department of pathology, Institute of Medicine, during the study period. Eighty percent $(80 \%)$ of these testicular biopsies were of orchidectomy specimen and $20 \%$ were small biopsies. Thirty percent of the total specimen comprised of undescended testis. Out of the total 70 cases, $11.4 \%$ (8/70) were diagnosed as malignant testicular tumor. Age wise distribution of the patients along with diagnosis is shown in Table 1.

\section{DISCUSSION}

Though the incidence of testicular cancer is low, it is one of the commonest malignancies occuring in young adults. As described in the literature, testicular tumors were rare in this study.

Undescended testis comprised 30\% (21 cases) of the total testicular biopsies received, however none of these cases showed malignancy.

Most of the malignant cases were seen in the 4 th and the 5 th decades, 2 cases each. Testicular tumors are limited to three age group, infancy, late adolescence to young adulthood (20-35 yrs) and 50 years and above. ${ }^{9}$

According to the literature, the histologic pattern and behavior of the tumor differ with each age period. Seminomas have not been reported in infants, while embryonal carcinoma and teratoma are the most common tumors of infancy and childhood. In young adults seminoma, embryonal carcinoma, teratoma, and teratocarcinoma are common but seminoma is more common in the fourth decade while spermatocytic seminoma and lymphoma occur in the elderly.

In this study, Non Hodgkin lymphoma (NHL) and spermatocytic seminoma were seen in elderly, pure seminoma occurred in the $4^{\text {th }}$ decade, while leukemic infiltration was noted in the $5^{\text {th }}$ decade of life.

Out of the total 8 malignant tumors in this study, $62.5 \%$ (5 cases) consisted of germ cell tumors. According to Mostofi et al., germ cell tumors constitute more than 94\% of testicular tumors. ${ }^{9}$ Among the 5 cases of germ cell tumors in this study, 2 (40\%) were mixed germ cell tumors, which is similar to that seen in other studies. In this study, a 1 case of mixed germ cell tumor comprised of teratoma and embryonal carcinoma, whereas other contained predominance of seminoma with embryonal carcinoma.

Seminoma (fig.1) comprises $35-71 \%$ of testicular tumors. In this study, seminoma consisted of $28.5 \%$ ( 2 cases) of all testicular tumors. This variation in data may be due to the small number of cases included in this study.

A single case (12.5\%) of choriocarcinoma (fig. 2) with metastasis to the lung was seen in the 5th decade. Pure choriocarcinoma are rare in ovary and testis. Though confined to patients in the second and third decade of life, it has also been reported in the 6th decade, which is in accordance with our study.

A solitary case (12.5\%) of NHL (fig.3), diffuse large B cell type was seen in 75 year old. Fonesca el al. reported median age at presentation of extranodal NHL to be 68 years. ${ }^{10}$ Primary testicular lymphoma accounts for about $1 \%$ of all lymphomas and is the most common testicular malignancy in men more than 60 years of age. ${ }^{11}$

Hodgkin lymphoma occurring primarily in testis has not yet been reported so far in the literature. Hodgkin lymphoma

Table 1: Histopathological diagnosis along with age distribution.

\begin{tabular}{|c|c|c|c|c|c|c|c|}
\hline \multicolumn{8}{|c|}{ Diagnosis } \\
\hline Age group & Seminoma & MGCT & Chorioca & NHL & Metastatic & Leukemic infiltration & Total \\
\hline $0-10$ & - & - & - & - & - & 1 & $1(12.5 \%)$ \\
\hline $11-20$ & - & - & - & - & - & - & 0 \\
\hline $21-30$ & - & 1 & - & - & - & - & $1(12.5 \%)$ \\
\hline $31-40$ & 1 & - & 1 & - & - & - & $2(25 \%)$ \\
\hline $41-50$ & 1 & - & - & - & 1 & - & $2(25 \%)$ \\
\hline $51-60$ & - & - & - & - & - & - & 0 \\
\hline $61-70$ & - & 1 & - & - & - & - & $1(12.5 \%)$ \\
\hline $71-80$ & - & - & - & 1 & - & - & $1(12.5 \%)$ \\
\hline Total & $2(25 \%)$ & $2(25 \%)$ & $1(12.5 \%)$ & $1(12.5 \%)$ & $1(12.5 \%)$ & $1(12.5 \%)$ & $8(100 \%)$ \\
\hline
\end{tabular}


was not seen in this study as well.

NHL is the commonest neoplasm presenting as metastasis to the testis comprising about $1 \%$ of testicular tumors. ${ }^{9}$ It may occur at any age group ranging from 21-87 years with most of the cases presenting in the $6^{\text {th }}$ and $7^{\text {th }}$ decades. One case presenting with metastatic NHL in the fifth decade was seen in the current study.

The reported incidence of leukemic infiltration of testis varies from $8-25 \%$ in the literature, but in most studies this figure is less than $10 \% .{ }^{12-14}$ In this study, a seven year old $(12.5 \%)$ presented with testicular involvement by acute lymphoblastic leukemia (ALL).

The testis represents a potential sanctuary site for tumor cells especially in ALL. ${ }^{15}$ The incidence of testicular leukemia has increased with the improved survival of childhood ALL. ${ }^{16}$

According to Mostofi et al, stromal tumors consist of 3\% of testicular tumors. However, in this study stromal tumors were not encountered. This could be due to the small number of cases in the study. Since, this study was limited by small number of cases, follow up study involving a larger study population is recommended.

\section{CONCLUSION}

Testicular tumors are uncommon in our population. Most common tumor was germ cell tumor as is evident in other parts of the world. However, unlike in the Western population, malignancy developing in the undescended testis is rare.

\section{REFERENCES}

1. Parkin DM, Whelan SL, Ferlay J, Raymond L, Young J. Cancer incidence in five continents [ PDFs online]. Vol VII Lyon: IARC scientific publications, 1997. [cited 2011 nov 5]. Available from: URL: http://www.iarc.fr/en/publications/pdfs-online/epi/sp155/ ci5v8-chap1.pdf.

2. Liu S, Wen SW, Mao Y, Mery L, Pouleau J. Birth cohort effects underlying the increasing testicular cancer incidence in Canada. Can J Public Health 1999;90:176-80.

3. Zheng T, Holford TR, Ma Z, Ward BA, Flannery J, Boyle P. Continuing increase in incidence of germ cell testicular cancer in young adults: experience from Connecticut, USA 1935-1992. Int J Cancer 1996;65:723-9.

4. Bergstrom R, Adami HD, Mohner M, Zatonski W, Storm H, Ekbom A et al. Increase in testicular cancer incidence in six European countries: a birth cohort phenomenon. J Natl Cancer Inst 1996;88:727-33.

5. Dos SS, Swerdlow AJ, Stiller CA, Reid A. Incidence of testicular germ cell malignancies in England and Wales: trends in children compared with adults. Int J Cancer 1999;83:630-4.

6. McGlynn KA, Devesa SS, Sigurdson AJ, Brown LM, Tasol, Tarone RE. Trends in the incidence of testicular germ cell tumors in the United States. Cancer 2003;97:63-70.

7. Moller H, Jorgensen N, Forman D. Trends in incidence of testicular cancer in boys and adolescent men. Int J Cancer 1995;61:761-4.

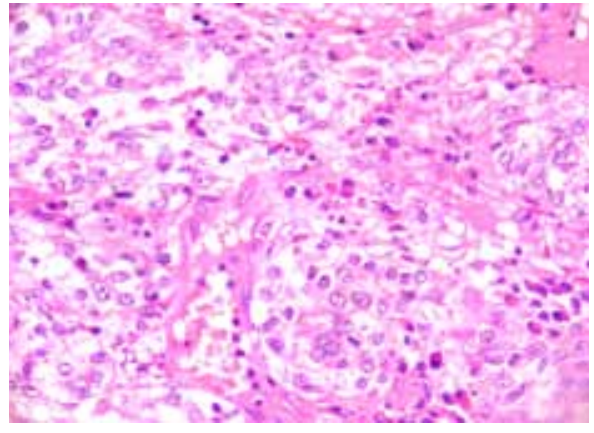

Figure 1: Seminoma. Nests of tumor cells separated by fibrous septa containing lymphocytes and plasma cells (HE stain, X200).

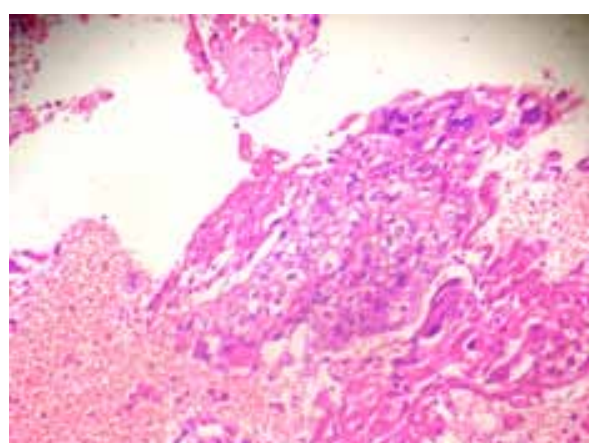

Figure 2: Choriocarcinoma. Biphasic pattern of cytotrophoblast and syncytiotrophoblast along with areas of necrosis (HE stain, X100).

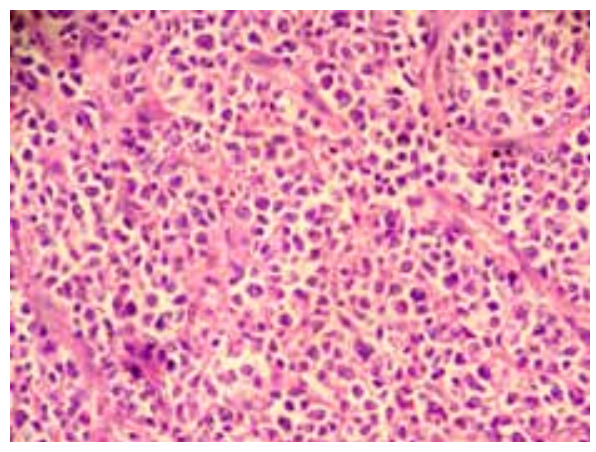

Figure 3: Non Nodgkin lymphoma. Relatively uniform population of atypical lymphoid cells having irregular nuclear contours (HE stain, X200).

8. Garner MJ, Turner MC, Ghadirian P, Krewski D. Epidemiology of testicular cancer: an overview. Int J cancer 2005;116:331-9.

9. Mostofi FK, Price EB, Jr. Tumors of the male genital system. Atlas of tumor pathology, fascicle 7, Series 2. Armed Forces Institute of Pathology; Washington D.C. 1973;pp1186-1200.

10. Fonseca R, Habermann TM, Colgan JP, O'Neill BP, White WL, Witzig TE, Egan KS et al. Testicular lymphoma is associated with a high incidence of extranodal recurrence. Cancer 2000;88:154-61.

11. Vural F, Cagirgan S, Saydan G, Hekimgil M, Soyer NA, Tombuloglu M. Primary testicular lymphoma. J Natl Med Assoc 2007;99:127782.

12. Stoffel TJ, Nesbit ME, Livitt SH. Extramedullary involvement of the testis in childhood. Cancer 1975;35:1203-11. 
13. Kuo TT, Tschang TP, Chu JY. Testicular relapse in childhood acute lymphoblastic leukemia during bone marrow remission. Cancer 1976;38:2604-12.

14. Braren V, Lukens JN, Stroup SL, Bolin MG, Rhamy RK. Testicular infiltrate in childhood acute lymphoblastic leukemia. The need for biopsy in suspected relapse. Urology 1980;16:370-4.
15. Coppes MJ, Rackley R, Kay R. Primary testicular and paratesticular tumors of childhood. Med and pediatric oncol 1994;22:329-40.

16. Poplack DG: Acute lymphoblastic leukemia. In Pizzo PA, Poplack DG (eds): Principles and practice of pediatric oncology. Philadelphia: JB Lippincott Company, 1989; pp323-66. 